\title{
Addison's Theater of the Aesthetic
}

Theater is the missing term of Addison's aesthetics. Over the eleven numbers of the Spectator that comprise his 1712 essay on the "Pleasures of the Imagination" (nos. 411-421), Addison considers painting, statuary, architecture, landscape gardens, and poetry, but conspicuously not the stage. 1 Of course, the trajectory of Addison's essay-which moves from consideration of imagination's primary pleasures (the experience of what we see) to its secondary pleasures (the reconstruction of the seen object in the mind) - is one that in any case privileges literariness. As Neil Saccamano notes, Addison's discussion of the secondary pleasures is "entirely determined by the substitution of poetic description, based on writing and speech, for the 'other Kinds of Representation' he singles out."2 But it's nonetheless striking that the "Pleasure" essay, an essay concerned with the experience and epistemology of the visual, doesn't so much as glance atsingle out - the theater.

Striking but not surprising, for Addison was always troubled by the embodiedness, the ineluctable sensuality, of performance. As part of their recurrent call for the regulation of the public stage in the Tatler and Spectator, both he and Steele routinely inveighed against the spectacular excrescences of contemporary theater. But unlike Steele — who readily acknowledged the singular moral efficacy of "seeing generous Things perform'd before our Eyes"—Addison's conception of drama is first and foremost rhetorical.3 His essays on tragedy in the Spectator pit the "well-written" play, with "its the Dignity of Thought and Sublimity of Expression," against the "the Dresses and Decorations of the Stage" (39, 1:164; 42, 1:177, 179). "However the Show and Outside of the Tragedy may work upon the Vulgar," Addison witheringly insists, "the more understanding Part of the Audience immediately see through it and despise it" $(42,1: 180)$. As in 
his "Pleasures" essay — and in a iteration of the "dichotomy of inside and outside" that Michael Ketcham finds to be the Spectator's presiding conceit - the image (the senses) is anxiously subordinated to the word (the rational mind).4 Indeed, as John O'Brien and Michael McKeon observe, Addison's various engagements with drama in the Spectator quietly and consistently substitute the reader for the spectator in an effort to keep the threatening materiality of the stage at bay. 5

What, though, of Addison the playwright? O’Brien regards Addison's works for the stage as exercises in "an antitheatrical mode of drama," but in fact Addison's acute sensitivity to the visual and material dimensions of performance makes him a sophisticated and unusual dramatist.6 Most obviously, Cato (1713) keeps both its most powerful presence-Caesar, whose imminent arrival shapes the plot and mood — and also its most sensational act of violence — stoic suicide — behind the scenes, while at the same time asking its audience to view the protagonist through the enraptured gaze of a proxy: the Numidian prince Juba. In its intricate dialectic of seen and unseen, the tragedy thus controls spectacle in part through its very staging of spectatorship. As I argue here, though, it is in Addison's first work for the stage, his longforgotten libretto Rosamond (1707), that we find his most complex and sustained engagement with the theater's dynamics of visuality. Working in what Robert Hume describes as "less a genre than ... a mode of production," a mode defined by its marshalling of spectacular visual effects, Addison's opera consciously experiments with theater as a medium both of visual thinking and for thinking the visual.7 Here, the spectators on stage are profoundly transformed by what and how they see in a scenographically elaborate drama that parses the constitution and possibilities of its own spectacularity. In short, Rosamond returns the theater to Addison's aesthetic thought. 
Dramatizing the story of King Henry II's affair with Rosamond Clifford, Rosamond overlays English myth, English verse, and English music in a Whiggish attempt to lay the ground for a genuinely native tradition of all-sung opera. In the event, it was withdrawn from the Drury Lane stage after just three performances, an embarrassing and costly failure that critics from that day to this have laid largely at the feet of composer Thomas Clayton.8 Only in the 1730s, with Addison long dead, would Rosamond achieve something like theatrical success, thanks to a new setting by the young Thomas Arne. Yet, for all its initial failure, this opera merits serious attention. As we'll see, there are striking correspondences of thought between Addison's libretto and his "Pleasures" essay, which was drafted by 1704 and thus both pre- and post-dates Rosamond.9 The governing claims of Addison's essay—that "Our Sight is the most perfect and most delightful of all our Senses" and that "by the Pleasures of the Imagination" he means "only such Pleasures as arise originally from Sight"-require him carefully to adjudicate between the senses and the imagination $(411,3: 535,537)$. Rosamond undertakes this same vexed negotiation at the level of its dramatic plot, which enacts a discernible and triumphant movement from sensual gratification (adulterous desire) to aesthetic delight (in the sublime and varied shape of history itself).

But I've no interest in proffering this play as an hitherto ignored footnote in the development of the "Pleasures" essay. Rather, I wish to suggest Rosamond's importance as a text—and event $—$ on two, interrelated counts. First, it significantly adds to and even alters our understanding of the interaction between the media of performance and periodical print in the early eighteenth century, a "nexus" that Stuart Sherman rightly regards Addison and Steele to have pioneered.10 Most obviously, Steele's many appeals for a reformed stage in the Tatler and Spectator laid the groundwork for his sentimental comedy, The Conscious Lovers (1722), while 
Addison's essays on tragedy likewise prepared the public for the Senecan form of Cato, a play that Steele then vociferously promoted in the Guardian. Rosamond, however, requires us differently to configure the traffic between these media. Here, in an inversion of the familiar model, the play precedes, and incubates potential material for, the published essay. Moreover, while we now readily recognize the complex and contradictory theatrical inflections of the Spectator's essays - thanks especially to the work of Ketcham and Erin Mackie-Rosamond rather asks us to conceive of the play as a form that might, at times, behave something like an essay; it asks that we approach theater as a space and medium for testing out and working through a series of hypotheses or provocations - in this case, to do with the moral and epistemological dimensions of aesthetic experience. 11

This, then, is my second contention: that Rosamond invites us to consider what it means for the theater to do aesthetics.12 What, I'm asking, if we regard the theater, as I believe Addison does in this instance, to be a vehicle for theorizing the aesthetic, a vehicle perhaps specially equipped for such work in formal and material terms? To pose this question is to strike at the long philosophical tradition that has posited theater — or, often more precisely, spectacle — as the other of contemplation, reason, and action. In Guy Debord, this tradition of course has its master interlocutor. Spectacle renders us passive, Debord tells us, it transfixes us with the illusory fiction of representation, it supplants and puts us at a distance from the real. Ideology, false consciousness, is spectacle.13 Plato, Rousseau, Marx, Lukacs, and—as Jacques Rancière observes - paradoxically even the likes of Bertolt Brecht and Antonin Artaud belong to this same fundamentally antitheatrical tradition. 14 So, too, if we turn to scholarship directly concerned with the European Enlightenment, does Michael Fried, for whom theatricality - that mode which 
unabashedly addresses its spectator - is the antithesis of the absorptive art (for Fried, the first "modern art") that emerges in eighteenth-century France. 15

To regard the theater as a potential site for and practice of theoretical work is to remind ourselves that theater and theory share the same etymological root: the Greek word theatron, from the verb theasthal, meaning "to behold." As Hans-Thies Lehmann notes, the history of Western philosophy and theory is defined by its resolute denial of this common origin with the theater and so too its relations to the body and the senses; theory has always regarded theater as the "inherently deficit double" of its own logos.16 In particular, Lehman reminds us, the long shadow cast by Aristotle's Poetics — which privileges plot (muthos) and speech (lexis) above spectacle (opsis) and cautions that the "appeal to the eye is inartistic"- has obscured the distinctness of theater's own mode of thinking, a mode in which gazes, gestures, bodies, movements, and interactions are the instruments and locations of thought.17 If we are properly to understand the theater as a place in which theory, in this case a theory of the aesthetic, might happen, then we need to cast aside a notion of argument's logic that is foreign to theater as something that happens, that takes form as an event and not as a text (for all that a text might be a constituent element of that event). Such a conception of theater's ontology is certainly anathema to the Addison behind Mr. Spectator, the Addison who rehearses the Aristotelian bias against opsis in his essays on tragedy and who programmatically evades discussion of the theater in his "Pleasures" essay. But Addison-the-librettist, the playwright fully and perhaps painfully aware of the potentialities of performance as a practice of showing and seeing, rather uses the manifold visual resources of the stage as the materials with which to grapple theoretically — to assay - the category of the aesthetic. 
In what follows, I first demonstrate that Addison's elaboration of the aesthetics of novelty in his "Pleasure" essay might counterintuitively be read as describing and validating exactly the kind of spectacular drama he elsewhere denigrates. In problematizing Addison's attempt to distinguish the senses from the imagination and in suggesting how conducive certain aspects of Addison's account of the imagination are to the experience of performance, this discussion then furnishes a platform for my reading of Rosamond as an experiment in aesthetics. The vital point of this reading is that the insights at which Addison arrives in his libretto are necessarily different than those of his "Pleasure" essay precisely because these insights are and must be profoundly shaped by the particularities of theater's medium. For one, its multimedial form draws out and differently inflects the paragonal structure of Addison's dramatic criticism, which opposes writing to picturing. In particular, opera requires Addison to engage with the functions of drama's "outside," of the regime of the image, as never before. For another, the embodied and situational nature of performance enables (or compels) Addison to register the erotics and, more especially, the ethics of the imagination-dimensions of the imagination's operations to which his essay doesn't directly attend.

Above all, performance, is not just about what is seen or heard; its ephemeral bodies become vectors in something entirely more abstract, namely the rituals of memory, individual and collective. For Addison, the imagination is a function of (if not a different way of naming) memory: the images impressed on the mind that can be recalled, remade, conjoined, or compared with others. Rosamond, I want to show, makes this connection between imagination and memory especially apparent—visible—because, as Herbert Blau famously puts it, "Where memory is, theatre is." 18 As Marvin Carlson argues, theater is a "memory machine" in which every aspect of theatrical production is "ghosted" by past performers and performances: 
the stories it chooses to tell, the bodies and other physical materials it utilizes to tell them, and the places in which they are told ... these production elements are also, to a striking a degree, composed of material "that we have seen before," and the memory of that recycled material as it moves through new and different productions contributes in no small measure to the richness and density of the operations of theatre in general as a sire of memory both personal and cultural. 19

Framed in terms of Addison's aesthetic theory, Carlson reminds us that performance is, in manifold ways, an associational engine; what he calls ghosting is a reflex and experience akin to Addison's secondary pleasures of the imagination. Both are ways of thinking about the aesthetic qualities, the aesthetic presence, of the ostensibly unseen and the absent. Rosamond, I contend, is intuitively alert to theater's associational dynamics and departs most radically from Addison's "Pleasures" essay in its suggestion that imagination's secondary pleasures might themselves be spectacular, that is, other than verbal. At its climax especially, which stages the very interior of the mind, the opera shows the unseen to be the domain less of language than of the theater's outsides: its bodies, its scenographies. As a result, Rosamond calls into question not only the binaries between showing and telling, seeing and reading, so forcefully rehearsed in Addison's critical essays, but more fundamentally his very distinction between imagination's primary and secondary pleasures, between seeing and remembering.

I. Theater and the Aesthetics of Novelty 
As the likes of Ronald Paulson and Scott Black have shown, of the three aesthetic categories that Addison adumbrates in his "Pleasures" essay—-the triad of the great (i.e. the sublime), the beautiful, and the uncommon - it is the last, what Addison sometimes calls "the strange" but more often "novelty," that does much of the conceptual heavy lifting and which indeed marks its most distinctive contribution to the field.20 As Addison writes in Spectator 412, the appeal of novelty speaks to the restless play of our attention:

Every thing that is new or uncommon raises a Pleasure in the Imagination, because it fills the Soul with an agreeable Surprise, gratifies its Curiosity, and gives it an Idea of which it was not before possest. We are, indeed, so often conversant with one Sett of Objects, and tired out with so many repeated Shows of the same Things, that whatever is new or uncommon contributes a little to vary Human Life, and to divert our Minds, for a while, with the Strangeness of its Appearance: It serves us for a kind of Refreshment, and takes off from that Satiety we are apt to complain of in our usual and ordinary Entertainments ... It is this that recommends Variety, where the Mind is every Instant called off to something new, and the Attention not suffered to dwell too long, and waste it self on any particular Object. $(412,3: 541)$

Addison finds ready proof of this argument in our response to the natural world; where we are "quickly tired" by a barren landscape, we take great pleasure in a prospect animated by water, 
plant life, or the passing of the seasons (412, 3:542). But the attractions of novelty and variety as Addison specifically describes them here - our love of the new, of sudden change, our distaste of repetition and sameness - might equally be deployed to legitimize exactly the spectacular aspects of drama that we've seen him to decry in his essays on tragedy.

This discomfort with drama's "Show and Outside" is especially pronounced in Addison's essays on opera. In Spectator 31, for instance, he offers a satirical portrait of a "Projector" who proudly presents his coffee-house audience with a "Scheme for an Opera" that will bundle into a single entertainment "all the remarkable Shows about Town" (1:128); while in Spectator 5, Addison launches his broadside against Italian opera by denouncing its "extravagantly lavish ... Decorations," the "only Design" of which "is to gratify the Senses, and keep up an indolent Attention in the Audience" (5, 1:22-23). But isn't this a matter of recognizing, just as Addison does in Spectator 412, the ease with which our minds weary of the familiar and our need to find new objects on which our attentions might linger? What's the difference between novelty as suspect cultural imperative, as the endless parade of theatrical sights, and novelty as a legitimate aesthetic category? When Addison writes in his "Pleasures" essay of "the Scene ... perpetually shifting, and entertaining the Sight every Moment with something that is new" might he not just as easily be taken as describing the pleasures of the theater, of stage effect $(412,3: 542)$ ?

To be sure, such questions overlook Addison's privileging of nature above art, though this judgment itself is partly undone almost as soon as it is given, with Addison admitting that "we find Works of Nature still more pleasant, the more they resemble those of Art" (414, 3:549). Again, we need to note that it is precisely the unnatural hyperbole and ontological confusions of scenographic representation that trouble Addison, who in his discussion of opera in Spectator 5 ridicules the sights of "an open Boat upon a Sea of Paste-Board ... painted Dragons spitting 
Wild-fire, enchanted Chariots drawn by Flanders Mares, and real Cascades in artificial Landskips" (1:23). Theatrical spectacle, on this account, collapses the distinction between the real and the represented, a move rendered all the more objectionable because the representational practice in question is so mimetically clumsy: "Shadows and Realities ought not to be mix'd together in the same Piece,” Addison contends, “...Scenes, which are designed as the Representations of Nature, should be filled with Resemblances, and not with the Things themselves" $(5,1: 23)$.

Yet Addison's focus on this confusion - in fact a constitutive feature of all performance, which involves an admixture of actual bodies and constructed props, costumes, and sets—is in part a rhetorical feint. By attending only to those instances in which the scenographer combines artificial and natural phenomena he conveniently side-steps analysis not only of the general issue of the representedness of painted scenery but also the specific problem of representing the supernatural. For while the implication of Addison's disparaging mentions of "Dragons" and "enchanted Chariots" is that the stage's predilection for the supernatural is unwarranted and ridiculous, this position would seem to be at odds with Addison's view in Spectator 419, where he expressly accommodates those depictions "wherein the Poet quite loses sight of Nature" to his theory of the imagination (3:570). There, however, Addison tellingly and fretfully limits his discussion to poetry, to the acts of writing and reading. He has nothing to say about how the theater, or for that matter any of the visual arts, might also engage the imagination in its depiction of "Ghosts, Fairies, Witches, and the like Imaginary Persons" (3:573). What's more, he briefly cites Buckingham's The Rehearsal — a play that sends up Dryden's spectacular theaterand then lavishes praises on Shakespeare for creating supernatural drama that touches "his Reader's Imagination" (419, 3:571, 573; emphasis added). To repeat the point with which I opened this essay, theater is the suppressed term of Addison's aesthetic. 
There remains, then, considerable tension between, on the one hand, Addison's aesthetic privileging of the new and varied and, on the other, his many denunciations of stage effect. In the first, the mind is seen to "waste it self" when it has only one object to attend to (Spectator 412); in the second, it does so rather in a confection of sights, such as that offered at the playhouse (Spectator 5). This tension should remind us that, for Addison, the pleasures of the imagination aren't, at heart, rational. Adapting John Locke's distinction between primary qualities (those that inhere in objects themselves, such as size and shape) and secondary qualities (those derived through the experience of the object's perceiver, such as color or taste), Addison posits that there are "primary" and "secondary" pleasures of the imagination: the first relate to the object seen and seeable, the second to the remembered image or idea of that object. But while the secondary pleasures don't directly involve sight, they nonetheless depend upon and ultimately spring from those primary pleasures, "which entirely proceed from such Objects as are before our Eyes" (411, 3:538). And these pleasures are, as Tony C. Brown notes, properly precognitive: "It is but opening the Eye, and the Scene enters," Addison writes: "The Colours paint themselves on the Fancy, with very little Attention of Thought or Application of Mind in the Beholder" (411, 3:538).21 The primary pleasures of the imagination aren't something we do or think or even necessarily seek out; they rather happen to us when we see something sublime or beautiful or novel. Just how different is this event of the aesthetic from the "indolent Attention" aroused and maintained in an audience by theatrical spectacle? Addison insists on the manifestly sensual operations of such spectacle ("its only Design is to gratify the Senses") but it seems to be a purpose-built machine for Addisonian novelty. To read theatrical experience as aesthetic experience, to read spectacle as novelty — that is, to do precisely what Addison doesn't do, 
precisely what he avoids doing - is to see how vexed is his distinction between the pleasures of the imagination and those of the senses, of the sight in particular.

This problem is most apparent in Addison's use of the word entertain and its cognates, which appear some sixteen times across the "Pleasures" essay. Addison employs the word in its original sense of "to keep up or maintain," as in "the Works of Nature and Art ... are qualified to entertain the Imagination" (414, 3:548). But this first sense often shades into a second, that of providing amusement or diversion: "We are every where entertained with pleasing Shows and Apparitions" $(413,3: 546)$. Entertainment as mentation (to entertain an idea or mental image) is invariably shadowed by entertainment as public performance, as culture industry. Once again, the terms in which Addison elaborates the aesthetic open the way for a readmission of exactly what they work to exclude — what Addison elsewhere refers to, with discernible irony, as "those Elegant Entertainments that are exhibited in our Theatres" (235, 2:413).

Such tensions reveal themselves with special force in Addison's epilogue to George Granville's semi-opera The British Enchanters, which premiered at the Queen's Theatre, Haymarket in February 1706. The verse form of the epilogue - defined by its specific place within the structure of public performance, its direct address to an audience, and its metatheatrical framing - obliges Addison to negotiate in writing precisely the problematic of the theater's novelty that his "Pleasure" essay evades:

The same dull sights in the same landscape mixt, Scenes of Still life, and points for ever fix'd, A tedious pleasure on the mind bestow, And pall the sense with one continu'd show: 
But as our two Magicians try their skill,

The vision varies, tho' the place stands still,

While the same spot its gaudy form renews,

Shifting the prospect to a thousand views.22

These lines rehearse, with striking precision, Addison's account in Spectator 412 of the mind becoming fatigued with the same view and of its consequent delight in the uncommon and the varied (an account, remember, already drafted by this date). The two magicians of Granville's play here stand as figures for the consummate scenographer, through whose transformative skill the playgoer may behold many places and yet sit still. The experience of spectacle is understood, unequivocally, in terms of the aesthetics of novelty.

However, in the final lines of the epilogue, Addison retreats from this position:

But howsoe'er, to please your wand'ring eyes,

Bright objects disappear and brighter rise:

There's none can make amends for lost delight,

While from the Circle we divert your sight.23

Addison here barely masks the anxiety with which he imagines the restless, never satisfied attentions of the public. Yet in his closing compliment — the "Circle" are the ladies sat in the theater's boxes - he simply redirects the audience's gaze from one sight to another. For having lingered on the pleasures of scenographic variety, Addison now abruptly concedes that such pleasures compete with and "divert" spectators from the "delights" of female beauty. It is a 
gesture of politeness that affirms the close relationship between the aesthetics of beauty and the protocols of sociability and sexual relations. In his "Pleasures" essay, after all, Addison suggests that God "has made every thing that is beautiful in our own Species pleasant, that all Creatures might be tempted to multiply their Kind, and fill the World, with Inhabitants" (413, 3:546). The epilogue's tribute to the "Circle" enacts this same admission, only here it takes the form of a commendation that directly acknowledges the immediate and proximate attractions of the bodies of women present in the playhouse, a site given over to embodiment, to physical and sexual transactions. And in fashioning a spectacle of the spectatrix - a favourite game of the Spectator, which repeatedly offers its readers accounts of female conduct at the playhouse-Addison's epilogue makes the beauties of the circle one more novelty in the theater's unceasing cycle of new sights.24 In its effort to return from the sensuality of stage representation to that supposedly more decorous world of the social, the epilogue succeeds only in collapsing the distinction between the two in a manner that exposes the fundamentally sensual basis of the aesthetic. Women become spectacular bodies, what in Spectator 73 Addison calls "Idols" (1:312-15), while in turn stage novelties become almost erotically charged.

In the curious negotiations of this epilogue we can see how far Addison's engagement with the practice of theater requires him to work through the fraught, always troubled relations between the pleasures of the senses and those of the imagination. And we can see, too, just how far writing for the stage compels Addison not only to wrestle openly with the aesthetics of embodied performance but also to use the forms of theater as modes of theoretical thought and proposition, especially as regards the nature of visual experience. In Rosamond, the three-act libretto he was writing at the very same time, he takes up this challenge of using the theater as a laboratory for aesthetic thinking in a far more sustained and complex manner. 25 


\section{The Drama of Imagining Imagining}

The legend of "fair Rosamond" tells of King Henry II's passion for his mistress, Rosamond, daughter of Walter de Clifford, and of his creation in the royal park at Woodstock of a bower, at the heart of a labyrinth, as a secure and private place for the couple's liaisons. Despite the King's precautions, however, his wife, Eleanor of Aquitaine, learns of the bower's location and has Rosamond murdered, with the bereft Henry arranging for his mistress's burial at nearby Godstow Abbey.26 The myth's location furnished Addison with a ready opportunity for Whig panegyric. In January 1705, Queen Anne had gifted the royal manor of Woodstock to John Churchill, 1 st Duke of Marlborough, in recognition of his victory at the Battle of Blenheim, and the following year, with John Vanbrugh appointed chief architect, work formally commenced on the construction of a house at Woodstock that would serve both as Marlborough's family seat and as a national monument to the triumph of 1704 . With Rosamond, Addison was in part returning to the political poetics of The Campaign, the verse celebration of Marlborough's exploits at Blenheim that had launched him to literary celebrity. But in Addison's version of the story Rosamond doesn't die and the King and Queen aren't irrevocably estranged. Rather, Eleanor drugs Rosamond with a sleeping draught and then dispatches her to Godstow to live out the rest of days in pious seclusion. Meanwhile, in a scene to which I'll turn later, Henry II receives a vision of England's glory to come (Vanbrugh's Blenheim included) that recalls him to both his royal and conjugal duties. Rosamond thus offers a knowingly playful exercise in revisionist history that uses comedy's structure of reconciliation and renewal and opera's spectacular form 
to stage the victory of the imagination over the senses - or rather, as I'll argue, the victory of the imagination through or in the senses.

As this summary suggests, the wholly reconceived figure of Queen Elinor-the largest role in the opera - acts as the pivot around which Addison rewrites the myth.27 Earlier iterations of the story invariably cast the Queen as a conspicuously French consort consumed by murderous rage.28 Addison's Rosamond turns this tradition on its head in its complex, sympathetic portrait of "Britain's Queen” (as she's repeatedly called), who in pulling back from violence enables reconciliations at once personal and political.29 More to the point, Elinor is offered to the audience of as a model of aesthetic subjecthood. When we first meet her, at the very opening of the opera, she appears in throes of imagination's pleasures as she gazes upon "A Prospect of Woodstock-Park, terminating in the Bower":

What place is here!

What scenes appear!

Where-e'er I turn my eyes,

All around

Enchanted ground

And soft Elysiums rise:

Flow'ry mountains,

Mossie fountains,

Shady woods,

Chrystal floods

With wild variety surprise. (1.1.1-11) 
This is exactly the kind of "spacious Landskip cut out into Rivers, Woods, Rocks, and Meadows" that Addison offers in Spectator 412 as an instance of "Beauty" and "Uncommonness joyned with ... Grandeur" (3:541). Rosamond, that is, opens with a scene that marshals the visual effects of the theater to stage the event of the aesthetic and to offer the audience the spectacle of engaged spectatorship. Almost immediately, however, this setup is punctured, as the Page's goading observation that in the distant bower "gentle Rosamond immured / Lives from the world and you secured" prompts a change in the Queen's attention and mood: "I faint, I die, / With secret pangs of jealousie" (1.1.18-21). What occurs in this moment is an abrupt transition from the seen (the environment immediately before both Elinor and the opera's audience) to the named but unseen (Rosamond in her bower). The drama here resides in the shift from image to word, sight to the mind's eye, imagination's primary to its secondary pleasures.

This shift—from out there to in here—is plotted in spatial terms. In the Spectator, Addison suggests that where in "a spacious Horison ... the Eye has Room to range abroad, to expatiate at large on the Immensity of its Views, and to lose it self amidst the Variety of Objects," so conversely the mind "naturally hates every thing that looks like a Restraint upon it, and is apt to fancy it self under a sort of Confinement, when the Sight is pent up in a narrow Compass" (412, 3:540-41). In this way, Elinor's near-fainting is both reflected and induced by the transferal of her attention from the expansive park she sees to the labyrinthine bower she imagines: "In such an endless maze I rove," she sings, "Lost in labyrinths of love" (1.1.42-43), and so consciously adopts the confined, disorienting space as a figure of her own psychological state. Such, for Addison, is the torment of the damned. Where heaven, he tells us in Spectator 237 , will grant the saved the varied prospect of eternity, hell will "bewilder" condemned souls 
“in Labyrinths of Error, Darkness, Distraction, and Uncertainty of every thing but their own Evil State." Hell, for Addison, is a state of epistemological torture, a notion he finds vividly realized in Paradise Lost, where Milton depicts "the fallen Angels reasoning together in a kind of Respite from their Torments, and creating to themselves a new Disquiet amidst their very Amusements" (237, 2:421). It's telling, then, that Rosamond's Elinor insists that her "wrath, like that of heav'n, shall rise / And blast her [Rosamond] in her Paradise" (1.1.32-33). That this simile fails, running up against the very language in which it is expressed, readily suggests the pained extent of her impaired reason. She would compare herself to the righteous Godhead but her circumstances and words rather posit her as a version of Milton's Satan, anguished by the idea of a paradise in which he cannot share. 30

The first fifty lines of the opera thus offer a highly condensed staging of the fall, now rendered in precise aesthetic terms as a movement from the primary to the secondary pleasures of the imagination. Only the ideas triggered by the Page's words provide no pleasure at all. In the figure of Elinor, Addison dramatically realizes his portrait in Spectator 421 of a "Distracted Person" whose "Imagination is Troubled," their "whole Soul disordered and confused." God, Addison warns, "can so exquisitely ravish or torture the Soul through this single Faculty, as might suffice to make up the whole Heaven or Hell of any finite Being” (3:579-80). Significantly, while this passing acknowledgement of the imagination as a source of pain comes only at the very close of Addison's "Pleasures" essay — more afterthought than anything else-it is the starting point of Rosamond: the catalyst of dramatic action. In its opening scene, the opera stages the imagination as a faculty that profoundly shapes not only how we respond to the world around us, but how we act and interact with it as we negotiate the pleasures and pains that attend 
thought. The implication of Elinor's turn from rapture at the natural landscape to jealous fury at mental images of her own making is that the imagination directs moral being.

When Elinor next appears on stage, in the second act, this hint is explicitly elaborated. Still wavering between exacting her revenge and treating Rosamond with mercy, Elinor fully grasps the personal and ethical implications of this choice specifically by exercising her imagination:

I see, I see my hands embru'd

In purple streams of reeking blood:

I see the victim gasp for breath,

And start in agonies of death:

I see my raging dying Lord,

And O, I see my self abhorr'd! (2.4.7-12)

Far more than in the opening scene, Elinor here dramatically figures those "Secondary Pleasures of the Imagination which flow from the Ideas of visible Objects, when the Objects are not actually before the Eye, but are called up into our Memories, or form'd into agreeable Visions of Things that are either Absent or Fictitious" (411, 3:537). "[F]ixt in thought," as her Page describes her (2.4.6), Elinor is the precise moral and temporal inversion of the sleepwalking Lady Macbeth, who is so stricken by guilt that the blood-soaked memories of her crimes spill into her perceptual present. Mentally staging for herself one possible future - in fact, the customary ending of the myth—Elinor pulls back from murder. The refrain "I see," sung four 
times in six lines of recitative, insists on this moment as one of sight, of witnessing, but there's nothing actually to be seen.

Once again, we might ask how far we can properly speak of the pleasures of the imagination at this moment. Yet Elinor's lurid verbalization of her mental picture does accord with Addison's explanation of the "delight" we take "in being terrified or dejected by a Description": such pleasure arises, Addison assures us in Spectator 418, not from the act of description itself but rather "from the Reflection" it prompts, for "When we look on such hideous Objects, we are not a little pleased to think we are in no Danger of them" (3:568). To confront those terrors conjured by art is to feel the pleasure of our physically security from that which nonetheless is immanent to the imagination - a point Burke will later elaborate. Elinor is certainly horrified by the image she mentally composes for herself, but in "seeing" it — that is, as its audience rather than its artist—-she understands the distance, morally and temporally, between it and herself. She isn't and doesn't have to be the future version of herself she imagines. A tragedy unfolds within Elinor's mind so that the legend might be rescued on stage as a comedy of forgiveness and conjugal affection. Genre pivots on what Addison calls "the Action of the Mind" (418, 3:566).

Elinor is a thorough realization of the Lockean subject, whose experience and understanding derive from the internalization of "external visible Resemblances" that her mind then pictorially (re)composes.31 But she is also much more than this. In choosing not to murder Rosamond precisely because she imagines doing so, she reveals the proximity between the aesthetic and the ethical, and shows the secondary pleasures of the imagination especially — those that compare, compound, reconfigure, and invent using the mind's ready storehouse of imagesto be essential to the exercise of moral agency. Nowhere in his "Pleasures" essay does Addison 
make a comparable attempt to outline the ethics of the imagination. There, as Saccamano notes, Addison's etiology understands the imagination's pleasures in terms of the mysterious workings of providential design - "The Supreme Author of our Being has so formed the Soul of Man, that nothing but himself can be its last, adequate, and proper Happiness" (413, 3:545)—but he otherwise leaves his reader simply to infer their ethical import.32 Rosamond, however, brings Addison far closer to Adam Smith: in curating her actions to herself before she undertakes them, Elinor approximates the impartial spectator of Theory of Moral Sentiments, who constantly and imaginatively surveils her own behavior by picturing it to herself.

Perhaps the most obvious - and surely the most tempting — line of argument would be to regard the aesthetic protocols of the moral conscience formulated in this scene as closely tied to the principle of the literary that Addison's "Pleasures" essay accords such special power. "Words, when well chosen," Addison tells us, "have so great a Force in them, that a Description often gives us more lively Ideas than the Sight of Things themselves" (416, 3:560). So adept is the compounding facility of Elinor's imagination that she has no need of spectacle: "The Imagination can fancy to it self Things more Great, Strange, or Beautiful, than the Eye ever saw," Addison insists (418, 3:569). Elinor's speech is, in essence, ekphrastic: it makes present through language what is absent - at least, to the patrons of Drury Lane. Certainly, both Addison and his audience would be well rehearsed in the special rhetoric of this moment. As Abigail Williams has shown, war poems of the early eighteenth century harnessed ekphrastic techniques, along with a highly charged idiom of blood and gore, as a means not simply of representing conflict but of making it emotionally and visually present to readers with no direct experience of battle.33 Addison was a skilled exponent in this poetics. Describing William III's victory at the Battle of the Boyne his 1695 Poem to His Majesty, his muse sees "the Boyn run thick with 
Human gore, / And floating Corps lye beating on the shore", while in The Campaign, he writes of how the "floods of gore that from the vanquisht fell / The marshes stagnate, and the rivers swell." 34 Indeed, Elinor's words - the "purple streams of reeking blood," the body of her rival starting "in agonies of death" - echo the royal messenger's earlier announcement that Henry has returned "From purple fields with slaughter spread, / From rivers choak'd with heaps of head" $(1.5 \cdot 3-4)$.

Might we thus take Rosamond to be incubating a resistance to theater's visuality within its very spectacular form? Certainly, this reading aligns neatly with Addison's privileging of word above image in his essays on tragedy:

A good Poet will give the Reader a more lively Idea of an Army or a Battle in a Description, than if he actually saw them drawn up in Squadrons and Batallions, or engaged in the Confusion of a Fight. Our Minds should be open'd to great Conceptions and inflamed with glorious Sentiments by what the Actor speaks, more than by what he appears. (42, $1: 180)$

Most immediately, this account establishes a connection between the moral efficacy of art and what are, though as yet unnamed, imagination's secondary pleasures - a connection not explicitly given in the "Pleasures" essay. Yet Addison's switching of reader for spectator, that telling substitution identified by O'Brien and McKeon, renders the first sentence's opposition of the seen and unseen as properly a contrast between reading and watching, between different modes of cultural consumption and the different media of print and performance. The second 
sentence then posits an entirely new juxtaposition, between the acts of telling and showing on stage, between different modes of dramatic diegesis, though Addison proffers this second distinction as if it were merely a reiteration of the first. This rhetorical sleight of hand allows Addison to sidestep the fact of theatrical embodiment even as he acknowledges that an actor must "appear." The false, silently posited equivalence between the experiences of reading printed text on a page and hearing a professional performer speak on a stage enables Addison to imagine the actor, or rather their lines, as essentially bodiless. What he avoids recognizing here is that in the theater the verbal must always show itself; on stage, words have an "outside" in the physical presence of “deep-Mouth'd Actors,” as Addison's early, anti-theatrical poem “The Play-House” acidly describes them. 35

In Act 2 Scene 4 of Rosamond, though, it is finally Elinor's body - that is, the body of leading English soprano Catherine Tofts—on which much of the work of making meaning depends. This isn't simply to note that Elinor performs description. Crucially, her "I see, I see" speech ends without the cryptic exclamation: "It is decreed-it shall be so" (2.4.20). For all her speaking of her mind, all her wrestling with an imagined future, Elinor doesn't tell the audience what she's decided to do. Only at close of the opera, long after playgoers have witnessed Rosamond's apparent poisoning, will Elinor inform Henry that she administered no more than "drowsie juices" that induced "borrow'd death" (3.3.79-84), and so finally make known the effects of her vivid imagining of murder. Addison teases us in the name of dramatic suspense, of course, but the local, immediate effect of this refusal to tell is that it momentarily fashions a space in which Elinor's body means without words. To be sure, she will sing again, but her line "it shall be so" is followed by "a pause," the only such stage direction in the entire libretto. For a 
few seconds, the spectacle of Elinor's body, her movement, gestures, and presence, is all that the audience experience.

Compare this to Cato, in which Addison constructs a verbal frame around the each of the play's corpses. For instance, the treacherous senator Sempronius dies-having disguised himself as Juba in an attempt to rape Cato's daughter-lamenting that he is “doom'd to fall ... “disfigur'd in a vile / Numidian dress." 36 The implication is clear: in a tragedy which insists that Roman-ness is a state of ethical being, Sempronius registers the poetic justice of his dying clothed as a non-Roman. This captioning of the spectacular body is even more emphatic in the play's two subsequent corpse scenes. At the end of Act 4, Cato speaks over the mangled body of his son, Marcus, and insists that those on stage and off read the corpse as a symbol of "love of virtue" and sacrifice in the "country's cause." 37 And at the tragedy's close, Addison not only conceals the act of wounding — his essays on tragedy censure the English audience's “delight in seeing Men stabb'd, poyson'd, rack'd, or impaled" (44, 1:187)—but has Cato explicitly and incongruously die in a posture of Christian penitence: "methinks a beam of light breaks in / On my departing soul. Alas, I fear / I've been too hasty." 38 Then, evidently still troubled that his audience might take the scene to valorize the act of stoic suicide, Addison adds a further gloss, with Lucius's closing couplets cautioning: "hence, let fierce contending nations know / What dire effects from civil discord flow." 39 As John Dennis observed, "the Moral which is foisted in at the latter end of this Play, is wholly Foreign to it." 40 Addison's Cato repeatedly commutes its corpses into stable moral emblems. It strives to shut down the associational potential of the spectacular body — its capacity to ghosted by multiple narratives — by folding the work of interpreting them, of rendering them as text, into the action of the play itself. It is a strategy that Cato shares with the Spectator, where, as Ketcham notes, even as Mr. Spectator attends to the 
expressions and gestures of those he encounters, he "translates the visual into the rhetorical" and "absorbs the gestures into the verbal fabric" of the essay.41 Bodies aren't to be trusted to speak for themselves.

Not so in Rosamond. For all the ekphrastic force of Elinor's words, they do not report what she is thinking — visualizing — at the moment she makes her choice. Instead, at this instant of decision and in the vital pause that follows, Rosamond's audience behold the body of someone silently imagining, of a body not captioned. In the absence first of expository words and then of any words at all, spectators are themselves invited - required — to imagine what Elinor's “decree" will involve and to do so through the performer's body. It is a brief but powerful moment that depends for its specific dramatic effect and suspense on the ghosting, on the one hand, of the known narrative of the myth (the one mentally conjured by the Queen) and, on the other, of the dictates of genre (opera, at this time, demands a happy ending)—dictates made visible for Drury Lane's patrons in the presence of Tofts, possibly cast by Addison, who had earned acclaim in the title roles of the operas Arsinoe (1705) and Camilla (1706) at the same theater. Rosamond actively cultivates the spectacular play of association that Cato suppresses. Here, the manner in which the actor "appears" is not opposed to the unseen ("the lively Idea") but rather acts as channel for and to it.

\section{The Spectacle of the Mind}

In its staging of the event of the aesthetic, its harnessing of the visual stuff of the stage to help spectators imagine a character imagining, the brief scene of Elinor's decision prepares the audience for the vision sequence that opens the third act. The opera's most sensational moment 
in theatrical terms, this scene marshals spectacle to think about the epistemological work of spectacle. Here, the slumbering Henry is visited by "two Angels suppos'd to be the Guardian Spirits of the British Kings in War and in Peace," who descend upon a "cloud"- -by means of the very winching mechanism that Addison satirizes in "The Play-House," where actors "Swing in Clouds and fill Machines." 42 The first Angel conjures a prophetic dream of victories over the French: "On fancy'd fields the Gaul shall bleed, / Cressy shall stand before his eyes, / And Agincourt and Blenheim rise" (3.1.26-28). The second then reveals to the King "The future prospect of the place" (3.1.45) — that is, of Woodstock Park and the bower - at which point a scenographic representation of Vanbrugh's plan of Blenheim Palace suddenly appears:

Behold the glorious Pile ascending! Scene changes to the Columns swelling, Arches bending, Plan of Blenheim Castle.

Domes in awful Pomp arising, Art in curious Strokes surprizing, Foes in figur'd Fights contending, Behold the glorious Pile ascending! (3.1.46-51)

Addison looks to the katabasis of the Aeneid Book 6, in which Aeneas beholds the spirits of his yet-to-be-born Roman descendants, and, more especially, to Books 11 and 12 of Paradise Lost, where the archangel Michael unfolds for Adam the course of human history down to the coming of the Messiah. Addison gives considerable attention to the latter episode in his Spectator essays on the poem, where he praises Milton for offering "an agreeable Variety in [Adam's] Visions" (363, 3:363). That is, the vision sequence of Paradise Lost provides Addison with a specific 
template not only of the sublime (Adam sees a "great Review" [3: 362]) but also of the uncommon. Henry, like Adam, experiences history as a spectacular changing of scenes.

Above all, this is a drama of the mind. The Angel of War calls upon the audience to bear witness to the effects of the vision on the sleeping Henry, effects that are understood first at the level of the physical symptom and then, in more complex terms, as cognitive event:

See, see, he smiles amidst his trance,

And shakes a visionary lance,

His brain is fill'd with loud alarms;

Shouting armies, clashing arms,

The softer prints of love deface;

And trumpets sound in ev'ry trace. (3.1.29-34)

The language at this moment unmistakably rehearses Addison's "Cartesian" account of association in the "Pleasures" essay:

The Sett of Ideas, which we received from such a Prospect or Garden, having entered the Mind at the same time, have a Sett of Traces belonging to them in the Brain, bordering very near upon one another; when, therefore, any one of these Ideas arises in the Imagination, and consequently dispatches a flow of Animal Spirits to its proper Trace, these Spirits, in the violence of their Motion, run not only into the Trace, to which they were more particularly directed, but into several of those that 
lie about it: ... But because the Pleasure we received from these Places far surmounted, and overcame the little Disagreeableness we found in them, for this Reason there was at first a wider Passage worn in the Pleasure Traces, and, on the contrary, so narrow a one in those which belonged to the disagreeable Ideas, that they were quickly stopt up, and rendered incapable of receiving any Animal Spirits, and consequently of exciting any unpleasant Ideas in the Memory. (417, 3:563)

How far Addison is properly invoking Descartes's Les Passions de l'âme remains a matter of contention. 43 But for our purposes what's significant is that this mechanist theory of the mindin which memory is matter and the landscape we see actively changes the equally physical topography of our brain — evidently informs Addison's understanding of the epistemology of theater in Spectator 39, where he avers that such "Diversions" as a "well-written tragedy" will "wear out of our Thoughts every thing that is mean and little" $(39,1: 164)$. Read alongside the mechanism of Spectator 417, as O'Brien observes, this wearing out must be taken to be literal.44 Only in this scene of Rosamond - a scene driven less by textual effects than by the elaborate deployment of painted scenery and stage machinery—it isn't words ("the well-written") but images that precipitate the overwriting of the "softer prints" impressed on Henry's mind by sexual gratification with those deeper and more permanent traces created by the pleasures of the imagination.

And these pleasures of the imagination, in particular those of novelty, here open on to those still finer pleasures of the understanding. The "secret Pleasure" we take in the "new or uncommon," Addison tells us in the Spectator, is part of God's design, for novelty makes us 
curious and curiosity compels "the Pursuit after Knowledge" (413, 3:545). In turn, the exercise of our understanding sometimes brings with it an aesthetic delight, with Addison offering the example of the Roman historian Livy, through whose "lively" descriptions and "admirable Picture" the "Reader becomes a kind of Spectator" (420, 3:574). It's striking that Addison here inverts his customary substitution of reader for spectator; writing only attains the degree of rhetorical efficacy that conjoins the aesthetic and the instructional when it is bequeathed the sense of liveness and presence inherent to theater's medium. The implication, unacknowledged in the "Pleasures" essay of course, is that performance far more than print—-seeing generous Things perform'd before our Eyes, " as Steele puts it-has a special power to unite the imagination with the understanding. In its dramatic structure, Rosamond's vision scene embraces this possibility: Henry is a spectator and it is history's properly spectacular form, delighting as it educates, that induces his recognition of his sovereign responsibilities in the project of nation building. In Rosamond, the ascendency of the imagination over the sexual drive, and the concomitant arrival of kingly understanding, depends both for Henry and the audience on an emphatically visual experience — as if, paradoxically, sensation is being mobilized to defeat itself.

This isn't to ignore the function of the verbal in a scene that involves telling as much as showing. The Angel's in-the-moment description of what's happening in and to Henry's mind renders epistemological change as an event akin to warfare: it's not just that the King witnesses, in his dream vision, the action at Crecy, Agincourt, and Blenheim but that his mind itself becomes a site of violent struggle as new "traces" of ideas overwrite old. In a meaningful way, this is the drama's battle scene, and, as we've seen, Addison argued that "Incidents of such Nature should be told, not represented" (42, 1:179). Yet the situational dynamics of performance, 
in which the modifications of the physical structure of the brain wrought by sense impression are reported to the audience as a dramatic event, nonetheless makes the mechanics of Addison's mechanism that much more explicit. The traces of sensual pleasure are not simply, and more neutrally, stopped up or worn away — as they are in the Spectator-but actively "defaced," and once this has been achieved the two Angels exultantly sing that "Glory strives / The field is won" (3.1.35-36): the field in question being the actual surface of Henry's mind. In its violence, its formal correspondence to a play's battlefield report, the Angel's neurophysiological account of association posits Henry's mind as something like an offstage body, unseen but nonetheless present as a physical fact within the opera's fictional space.

My point is that this scene's specific attention to Henry's mind as a site at once corporeal and dramatic means that even as it enacts an ethical movement - an epistemologically violent movement - away from the pleasures of the body and towards those of the imagination, the body and senses nonetheless remain peculiarly in play, both verbally and visually. So, when Henry wakes, "starting from the couch" on which he has slept, he immediately signals the triumph of the imagination, the return of the rational and ethical self, in stridently sensual terms: "Where have my ravished senses been? / What joys, what wonders, have I seen!" (3.1.61-62). Addison only uses the verb "ravish" once in his "Pleasures" essay; there, striving to isolate the pleasures of the imagination from those of the senses, his aesthetic distinguishes itself from that of John Dennis in its relative eschewal of passion and enthusiasm. Yet as Kathleen Lubey argues, Addison's essay nonetheless aestheticizes the erotic: even as "Addison seeks to 'discredit' pleasures that would be vulgar or overly sensual ... he yet conceives of the spectator's body as desirous and aroused, and powerfully so, for the imagination to be aptly engaged." In Addison's account, the body is vital to the operations of the imagination, Lubey reminds us, while in turn 
the imagination "redeems spectators by preventing their enjoyment from manifesting in the body." 45 However, as we've already seen in Addison's epilogue for The British Enchanters, such a gambit is hardly possible in the embodied space of the theater. As Henry's words and the visible fact of his woken, thrilled body announce, this vision constitutes an erotic encounter with history itself. How could it be otherwise, when it has affected him in such an intensely neurophysiological way, literally creating new pathways on the surface of his brain? The pleasures of the imagination are here no more or less than those of the "ravished senses."

And as this scene reveals the complex entanglement of the pleasures of the senses, imagination, and understanding — all of which remain powerfully rooted in the body—so too does it trouble the distinction between the primary and secondary pleasures. Which of these, after all, does Henry enjoy in his vision? Seemingly, the King experiences the primary pleasures of the imagination, "which entirely proceed from such Objects as are before our Eyes," and yet he doesn't actually see anything. He is the spectator of spectacular theater whose senses are both "ravished" and wholly circumvented. Perhaps this discloses Addison's attempt to put Henry's body temporarily at something of a remove, his discomfort with the aesthetic as a fully embodied experience. But that Henry sees with his eyes closed, the Angels directly transmitting the "prospect" into (or rather, onto) his cerebrum, only makes the issue of the aesthetic subject's passivity ("It is but opening the Eye, and the Scene enters") that much more obvious. The slumbering Henry might almost be taken to instantiate the "indolent Attention" of an audience entertained by opera's "extravagantly lavish Decorations." That the vision happens to him, that his senses are "ravished" by it, only reinforces his apparent lack of agency.

Except that this scene of anagnorisis—-"a change from ignorance to knowledge," as Aristotle puts it—absolutely depends on Henry as an agent, his ethical subjecthood, his royal 
identity, recuperated in and through the aesthetic encounter.46 Unlike Juba, a proxy but static spectator who is given to Cato's audience as a character already changed by what he's beheld, Henry—like Elinor_ offers Rosamond's audience an onstage drama of transformative spectatorship, of moral reformation precipitated by an act of "seeing." Henry is Addison's "Man of Polite Imagination," able to "converse with a picture" and taking such delight in what offers itself to his eye that he has "a kind of Property in everything he sees" (411, 3:538), in this case the contours of the nation's destiny. "What joys, what wonders, have I seen! / The scene yet stands before my eye" (3.1.62-63), he sings in the moments after waking. There is a familiar movement from sight to memory here, from the primary to the secondary pleasures, but this movement is complicated by the drama of the dream: the scene, by definition, hasn't presented itself to his eye and yet, the vision over, it stands before his eye now. In employing this phrase Addison likely recalls John Evelyn's translation of Roland Fréart Parallèle de l'architecture antique et modern $(1650 ; 1664)$, where, in a passage on the Doric order that Addison quotes in Spectator 415, Fréart argues that when "the Eye, behold[s] nothing little and mean, the Imagination may be more vigorously touched and affected with the Work that stands before it" (3:556). Henry, likewise, is enraptured by the splendor of a neo-classical building, but is he seeing or imagining it at this moment? Addison in fact plays with this confusion, with Henry declaring: "My waking life appears a dream" (3.1.72). So "vigorously" have the images that Henry hasn't seen with his eyes "touched" his imagination — reshaping his mind—-that the relationship between sensible and mental worlds remains in flux even once he's fully conscious. This elision of primary and secondary pleasures is arguably more acute in Rosamond's audience. They do see at least part of Henry's vision: the plan of Blenheim, likely a large drop painted with an architectural elevation of the north front of the building. That is, the contents of 
Henry's vision aren't just reported, they are also in part shown; spectacle here represents a mental image or idea. The "Outside" of performance shows playgoers the interior of Henry's mind, where, moreover, they behold a notional image, for in 1707 Blenheim is no more than a "plan." And like Elinor's body in that critical moment of decision in the second act, this representation of the yet-to-be (or could it be a representation of an architectural drawing, a representation of a representation?) establishes the associational matrix on which the scene as a whole depends. In the "plan of Blenheim Castle" Addison overlays two technologies of cultural memory, fashioning in performance—where, as Joseph Roach comments, "memory operates as an alternation between retrospection and anticipation"- a monument to the past that will be realized in the future. 47 In its complex temporality, the spectacle of Blenheim thus invites the opera's audience imaginatively and simultaneously to conjure for themselves a constellation of unseen and unspoken images: Marlborough triumphant on the battlefield of 1704; Vanbrugh-the architect himself imagining "the future prospect of the place" and planning an architectural celebration of a modern, Whiggish Britain; and, above all, the in-process transformation of the Woodstock landscape, the construction of Blenheim Palace on the very site of the well-known "ruines" of Rosamond's bower (3.1.44).

This last idea is especially important, for, as Bream Hammond notes, by the time of the opera's performance these ruins were threatened with demolition.48 The painting of Vanbrugh's plan depicts an event as much as an object. In calling on the audience to witness the sight of Blenheim ("See, see"), the Angels don't interpret it, again in contrast to the textually-tagged bodies of Cato; rather, the present continuous tense of their description - "Columns swelling, Arches bending"- reinforces the status of the image suddenly and spectacularly discovered to the audience as the picturing of a coming into being: as something that is happening, not 
something which has happened or will happen. By means of association, of ghosting, the image of Blenheim becomes a visible, topographical figure for what is occurring to the surface of Henry's mind, where the traces of his adulterous passion are at that moment being erased as thoroughly and materially as they are in the renovated landscape of Woodstock Park. More than any single speech or song in Rosamond, it is the painted drop of Blenheim Palace-a piece of scenery specially commissioned, at some expense, for this opera - that takes the audience towards "Objects ... not actually before the Eye, but [which] are called up into ... Memories, or form'd into agreeable Visions of Things that are either Absent or Fictitious." In showing the mind, as he does in this scene, Addison summons his audience to find and take delight in the manifold unseen ideas that are imminent to the spectacular.

In the "Pleasure" essay, Addison comes closest to acknowledging this imminence when he writes of the "double Principle" by which pleasure "arises ... from the Agreeableness of the Objects to the Eye, and from their Similitude to other Objects," a reflex that for Addison explains why we discern "accidental Landskips of Trees, Clouds and Cities ... in the Veins of Marble, in the curious Fret-work of Rocks and Grottos" (414, 3:550). But this "double Principle" doggedly retains the very duality of Addison's aesthetic that it might seem to call into question. The implication that there aren't two discrete mental processes occurring here, that in fact we are always already seeing associationally, that subject and object converge, is swiftly closed down by Addison's insistence that this principle is a matter of comparative referentiality, most especially of the copy to the original. The double principle, as Sean Silver and Jonathan Lamb note, is essentially ekphrastic: it names the means by which description implies its absent original.49 Equally, in Spectator 416, Addison grants that the visual and textual representations function similarly, but does so in a statement that summarily evades precisely what it announces, 
as he writes of his intention to "confine" his essay "to those Pleasures of the Imagination, which proceed from Ideas raised by Words, because most of the Observations that agree with Descriptions, are equally Applicable to Painting and Statuary" (416, 3:560). Word subordinates image even in the very gesture that posits their supposed equivalence, an equivalence that Addison then swiftly eschews: "As we look on any Object, our Idea of it is, perhaps, made up of two or three simple Ideas; but when the Poet represents it, he may either give us a more complex Idea of it, or only raise in us such Ideas as are most apt to affect the Imagination" (416, 3:561). Words, Addison maintains, have a special power. Visual modes of representation, it seems, too readily risk collapsing the vital distinction between the work of the senses and the work of the mind.

Rosamond challenges this logic in its marshalling of the visual stuff of theater-the bodies of performers, the painted scenery—as the representational means of raising "complex" ideas in the minds of its spectators. In Addison's libretto, it is through the very "Show and Outside" of performance that the imagination is both staged and most powerfully exercised. Twice Rosamond deploys spectacle in ways that compel its audience to imagine characters imagining — in ways that spectacularize the mind — and in doing so it nurtures an associative mode of seeing and posits "appearance" (decorations, bodies) as a mode of depth, not surface. In what we might term Rosamond's poetics of spectacle, the distinction between imagination's primary and secondary pleasures — between the passivity of the mind in which sights "paint" themselves on the imagination and the action of the mind in which the imagination sifts and reorganizes the memories of such objects—becomes almost impossibly vexed. The conception of the primary pleasures adumbrated in the Spectator, of the "simple Ideas" that pertain to the act of looking, presumes that we see innocently, neutrally, passively. As a place or machine of 
memory, theater gives the lie to this notion. Rosamond explores, and depends dramatically on, the sight of an object as something inevitably and inexorably ghosted by what isn't there, by the memories and ideas we bring to each and every sense experience aside from any conscious, critical act of comparison or reference.

Yet however much this ghosting might be harnessed by a playwright, as it is by Addison in Rosamond, it is not easily to be controlled. Look again at Addison's conception of the singular work of poetic description in Spectator 416: the unrivalled efficacy of language, he contends, is not only that it allows the poet to open up an unseen and unseeable vista but also that it enables him only to "raise in us such Ideas as are most apt to affect the Imagination"- that is, words can be wielded actively to close down undesirable routes of memory. 50 Not so the seen, which, for Addison, as he discloses in the example of the "accidental Landskips" glimpsed in the block of marble, are more readily susceptible to "the Works of Chance" $(414,5: 550)$, to the contingencies of association. Hence, for instance, Cato's anxious use of text to police what and how spectacular bodies means. That Addison so entirely retreats from the insights fostered in Rosamond's assaying of the imagination, both in his "Pleasures" essay and in the tragedy that would bring him such theatrical success, suggests how far his experiment in spectacular theater as theory troubled the aesthetic and ontological hierarchies — word over image, mind over body, polite over vulgar, inside over outside — on which he wished his thought to rest.

I would like to thank Ephraim Levinson, Tina Lupton, and Daniel O'Quinn for their insightful comments on earlier versions of this essay. I also greatly benefitted from the thoughts and 
questions of members of the eighteenth-century culture seminars at the Huntington Library and the universities of Oxford and York, with whom I workshopped portions of this material. 1 The Spectator, nos. 411-421. All quotations from Spectator, ed. Donald F. Bond, 5 vol. (Oxford: Clarendon Press, 1965). Hereafter cited parenthetically by issue, volume, and page number.

2 Neil Saccamano, “The Sublime Force of Words in Addison's 'Pleasures'," ELH 58.1 (1991), 83-106 (91). Saccamano is quoting Spectator 416 (3:559).

3 The Tatler, ed. Donald F. Bond, 3 vol. (Oxford: Clarendon Press, 1987), 1:73-74.

4 Michael G. Ketcham, Transparent Designs: Reading, Performance, and Form in the Spectator Papers (Athens, GA: University of Georgia Press, 1985), 63.

5 John O'Brien, Harlequin Britain: Pantomime and Entertainment, 1690-1760 (Baltimore: Johns Hopkins University Press, 2004), 72-84; Michael McKeon, “The Dramatic Aesthetic and the Model of the Scientific Method in Britain 1600-1800," The Eighteenth-Century Novel 6-7 (2009): 237.

6 O’Brien, 76.

7 Robert D. Hume, “The Politics of Opera in Late Seventeenth-Century London," Cambridge Opera Journal 10.1 (1998): 43.

8 See A Critical Discourse on Opera's and Musick in England, appended to A Comparison between the French and Italian Musick and Opera's (London: William Lewis, 1709), 69; Roger Fiske, English Theatre Music in the Eighteenth Century, 2nd edn. (Oxford: Oxford University Press, 1986), 47; and Curtis A. Price, "Political Allegory in Late Seventeenth-Century English Opera," in Music and Theatre: Essays in Honour of Winston Dean, ed. Nigel Fortune (Cambridge: Cambridge University Press, 1987), 22. 
9 The manuscript of the "Pleasures" essay is held at the Houghton Library, Harvard University, MS Eng 772. A digital scan is available here: <https://iiif.lib.harvard.edu/manifests/view/drs:50974950\$8i>. For a transcription see Some Portions of Essays Contributed to the Spectator by Mr. Joseph Addison: Now first Printed from His Note Book, ed. James Dyke Campbell (Glasgow: Printed for J. D. Campbell, by Bell and Bain, 1864). The precise dating of this notebook is contested. The ruled pages and neat handwith later corrections in a hand recognizably Addison's — suggest it may have been written while Addison was at Oxford in the 1690s, but Marjorie Hope Nicholson rather dates the draft to around 1704 (Mountain Gloom and Mountain Glory: The Development of the Aesthetics of the Infinite [Ithaca: Cornell University Press, 1959], 301 n. 35, 307-08). 10 Stuart Sherman, ““"The General Entertainment of My Life”: The Tatler, the Spectator, and the Quidnunc's Cure,” Eighteenth-Century Fiction 27.3-4 (2015): 343-71.

11 Ketcham; Erin Mackie, Market à la Mode: Fashion, Commodity, and Gender in The Tatler and The Spectator (Baltimore: Johns Hopkins University Press, 1997).

12 For an earlier attempt to approach drama as a mode of epistemological and aesthetic inquiry see Eric Jager, “Educating the Senses: Empiricism in Dryden's King Arthur," Restoration: Studies in English Literary Culture, 1660-1700 11.2 (1987): 107-16. Jager reads Dryden's play as engaging the Molyneux Question.

13 Guy Debord, Society of Spectacle, trans. Ken Knabb (London: Rebel Press, 2004). 14 Jacques Rancière, The Emancipated Spectator, trans. Gregory Elliott (London: Verso, 2009), $1-8$. 
15 Michael Fried, Absorption and Theatricality: Painting and Beholder in the Age of Diderot (Berkeley and London: University of California Press, 1980). See also Fried's “Art and Objecthood," Artforum 5 (June 1967): 12-23.

16 Hans-Thies Lehmann, Tragedy and Dramatic Theatre, trans. Erik Butler (London: Routledge, 2016), 27-28.

17 Aristotle, Poetics, trans. W.H. Fyfe (Cambridge, MA: Harvard University Press, 1932), 1453 b. 18 Herbert Blau, The Audience (Baltimore: Johns Hopkins University Press, 1990), 382. 19 Marvin Carlson, The Haunted Stage: The Theatre as Memory Machine (Ann Arbor: University of Michigan Press, 2001), 3-4. See also Joseph Roach, Cities of the Dead: Circum-Atlantic Performance (New York: Columbia University Press, 1996) and Rebecca Schneider, Performing Remains: Art and War in Times of Theatrical Reenactment (London and New York: Routledge, 2011).

20 Ronald Paulson, The Beautiful, Novel, and Strange: Aesthetics and Heterodoxy (Baltimore: Johns Hopkins University Press, 1996), 48-74; Scott Black, “Addison's Aesthetics of Novelty," Studies in Eighteenth-Century Culture 30 (2001): 269-88.

21 Tony C. Brown, The Primitive, the Aesthetic, the Savage: An Enlightenment Problematic (Minneapolis: University of Minnesota Press, 2012), 75.

22 Joseph Addison, "Epilogue to The British Enchanters," 11. 13-20, in vol. 1 of Addison, The Miscellaneous Works, ed. A. C. Guthkelch, 2 vol. (London: G. Bells and Sons, 1914). 23 Addison, "Epilogue to The British Enchanters," 11. 23-26. 24 See, for instance, Spectator nos. 45, 73, 163, 208, 270. 
25 Addison presented a manuscript of Rosamond to Sarah Churchill, the Duchess of Marlborough, which is now in the Houghton Library, Harvard University, MS Hyde 11. The date inlaid on the manuscripts later binding reads "April 2nd, 1706."

26 For a survey of the sources on which Addison's libretto likely draws see Brean S. Hammond, “Joseph Addison's Opera Rosamond: Britishness in the Early Eighteenth Century,” ELH 73.3 (2006): 609-16.

27 Elinor has 1,208 words, compared to Henry's 944 and Rosamond's 891; she also sings both the first and, with Henry, the final lines of the opera.

28 See, for instance, Thomas May's seven-book poem The Reigne of King Henry the Second (London: A. M. for Benjamin Fisher, 1633), which compares Eleanor of Aquitaine to Medea (I3v); John Bancroft's rabidly anti-Catholic tragedy, Henry the Second, King of England; with the Death of Rosamond (London: Jacob Tonson, 1692); and William Harrison's poem Woodstock Park (London: Jacob Tonson, 1706), which equates Rosamond with Elizabeth I and Eleanor with Mary I (7).

29 Joseph Addison, Rosamond (1707), 2.4.14 and 2.6.11, 14, in vol. 1 of Miscellaneous Works. Henceforth cited parenthetically by act, line, and scene number.

30 Elinor's words specifically recall John Dryden's stage adaptation, The State of Innocence, and Fall of Man (pub. 1677), where Satan witnesses Eve embraced by Adam and wishes to "blast her, in the act of love" (3.1.95), in vol. 12 of The Works of John Dryden, ed. Edward Niles Hooker et al., 20 vol. (Berkeley: University of California Press, 1956-2002).

31 John Locke, Essay Concerning Human Understanding, ed. Peter H. Nidditch (Oxford: Clarendon Press, 1975), 163. 32 Saccamano, 89-90. 
33 Abigail Williams, “'Terrible Delight': Art, Violence, and Power in Early Eighteenth-Century War Poems," in Emotions and War: Medieval to Romantic Literature, ed. Stephanie Downes, Andrew Lynch, and Katrina O’Loughlin (Basingstoke: Palgrave Macmillan, 2015), 203-17. 34 A Poem to His Majesty. Presented to the Lord Keeper, 11. 15-16, and The Campaign, 11. 35152, both in vol. 1 of Miscellaneous Works.

35 Joseph Addison, "The Play-House," in A Pacquet from Parnassus: or, A Collection of Papers. Vol. I. No. II. (London: J. How, 1702), 19. Christopher Edwards confidently attributes this anonymously published poem to Addison in "Joseph Addison and the Authorship of "The Play House," Review of English Studies 34.133 (1983): 21-27. 36 Joseph Addison, Cato, 4.2.21-22 in vol. 1 of Miscellaneous Works. Henceforth cited parenthetically by act, line, and scene number.

37 Cato, 4.4.155-56.

38 Cato, 5.4.94-96.

39 Cato, 5.4.107-8.

40 John Dennis, Remarks Upon Cato (1713), in The Critical Works of John Dennis, ed. Edward Niles Hooker, 2 vol. (Baltimore: Johns Hopkins Univ., 1939), 2:45.

${ }_{41}$ Ketcham, Transparent Designs, 40-41.

42 Joseph Addison, Rosamond (1707), 3.1.1.sd, in vol. 1 of Miscellaneous Works, henceforth cited parenthetically by act, line, and scene number; Addison, "The Play-House," 19. ${ }_{43}$ See Hilbert. H. Campbell, “Addison's 'Cartesian' Passage and Nicholas Malebranche,” Philological Quarterly 46.3 (1967): 408-412; and Sean Silver, The Mind is a Collection: Case Studies in Eighteenth-Century Thought (Philadelphia: University of Pennsylvania Press, 2015), $137-39$. 
44 O’Brien, 78.

45 Kathleen Lubey, “Erotic Interiors in Joseph Addison's Imagination,” Eighteenth Century

Fiction 20.3 (2008): 419, 431.

46 Aristotle, 1452a.

47 Roach, 33.

48 Hammond, 605-9.

49 Silver, 135; Jonathan Lamb, The Things Things Say (Princeton: Princeton University Press, 2011), 117-22.

${ }_{50}$ On this function of description see Saccamano, 92-93. 